\title{
Diagnosis and treatment of early and delayed cerebral injury after aneurysmal subarachnoid hemorrhage
}

Citation for published version (APA):

Veldeman, M. M. (2021). Diagnosis and treatment of early and delayed cerebral injury after aneurysmal subarachnoid hemorrhage. [Doctoral Thesis, Maastricht University]. Maastricht University. https://doi.org/10.26481/dis.20210915mv

Document status and date:

Published: 01/01/2021

DOI:

10.26481/dis.20210915mv

Document Version:

Publisher's PDF, also known as Version of record

\section{Please check the document version of this publication:}

- A submitted manuscript is the version of the article upon submission and before peer-review. There can be important differences between the submitted version and the official published version of record.

People interested in the research are advised to contact the author for the final version of the publication, or visit the DOI to the publisher's website.

- The final author version and the galley proof are versions of the publication after peer review.

- The final published version features the final layout of the paper including the volume, issue and page numbers.

Link to publication

\footnotetext{
General rights rights.

- You may freely distribute the URL identifying the publication in the public portal. please follow below link for the End User Agreement:

www.umlib.nl/taverne-license

Take down policy

If you believe that this document breaches copyright please contact us at:

repository@maastrichtuniversity.nl

providing details and we will investigate your claim.
}

Copyright and moral rights for the publications made accessible in the public portal are retained by the authors and/or other copyright owners and it is a condition of accessing publications that users recognise and abide by the legal requirements associated with these

- Users may download and print one copy of any publication from the public portal for the purpose of private study or research.

- You may not further distribute the material or use it for any profit-making activity or commercial gain

If the publication is distributed under the terms of Article $25 \mathrm{fa}$ of the Dutch Copyright Act, indicated by the "Taverne" license above, 
Samenvatting 


\section{Samenvatting}

Een subarachnoïdale bloeding $(S A B)$ is een ernstige aandoening veroorzaakt door de ruptuur van een cerebraal aneurysma. Het is een vorm van hersenbloeding die in vergelijking met andere types van beroerte vaker voorkomt bij relatief jonge patiënten. De acute bloeding kan leiden tot plotselinge dood en patiënten die de bloeding overleven zijn vaak betroffen door langdurige of blijvende invaliditeit. Naast de directe schade die de eigenlijke bloeding aan het hersenweefsel kan veroorzaken komt het in een derde tot de helft van de gevallen tot verdere indirecte schade aan hersenweefsel in de dagen volgend op de bloeding. Oorspronkelijk werd deze indirecte of secundaire cerebrale beschadiging toegeschreven aan de vaatverengingen of vasospasmen die typische bij SAB patiënten kunnen ontstaan ca. vanaf een vier tal dagen na de bloeding. Huidig onderzoek heeft echter aangetoond dat vasospasmen slechts één van vele factoren zijn dewelke bijdragen tot zogenoemde laattijdige cerebrale ischemie (ofwel "delayed cerebral ischemia").

Het is de vroegtijdige diagnose en het succes van behandeling van deze latere secundaire ischemie, die voornamelijk de toestand bepaald in dewelke patiënten deze ziekte zullen doorstaan. Indien dreigende ischemie tijdig kan worden gedetecteerd kan behandeling hiervan het verder ontwikkelen van een herseninfarct, in dit gebied met zuurstof en glucose tekort, voorkomen. In patiënten die na de bloeding wakker en klinisch te onderzoeken zijn wordt delayed cerebral ischemia gedefinieerd aan hand van een klinisch neurologisch onderzoek. Helaas verkeren meer dan een derde van de betroffen patiënten in een toestand die te slecht is om een klinisch onderzoek uit te voeren. Er bestaat tot op heden geen consensus hoe dreigende ischemie in deze groep van patiënten die ten gevolge van de bloeding of latere complicaties niet bij bewustzijn zijn, dient te worden gedetecteerd.

In een eerste fase van het onderzoek dat tot dit proefschrift heeft geleid werd onderzochten in welke mate inhalatie van het edelgas Xenon kan bijdragen tot bescherming van de hersenen in de eerste 24 uur na een subarachnoïdale bloeding. Ondanks het feit dat edelgassen chemisch inert zijn, zijn ze in staat een biologische effecten uit te oefenen. Het edelgas Xenon, indien toegepast in de correcte dosering, kan sedatie induceren en gebruikt worden om een anesthesie uit te voeren. Het proefdierkundig onderzoek, gepresenteerd in hoofdstuk 2, is de eerste preklinische studie die de biologische effecten van Xenon in een experimenteel SAB model beoordeelt. Onze resultaten toonden aan dat de initiële drukverhoging binnen de schedel na een subarachnoïdale bloeding minder directe schade aan hersenweefsel veroorzaakt als de dieren met Xenon-gas werden behandeld. 
In een tweede fase werd in een patiënten collectief van meer dan 300 individuen met subarachnoïdale bloeding, een voor en na analyse uitgevoerd met betrekking tot de applicatie van invasieve multimodale neuromonitoring. Invasieve neuromonitoring bestaat uit de praktijk sondes te implanteren in de hersenen die in staat zijn continu de hoeveelheid zuurstof als ook de concentratie van geselecteerde metabolieten, te detecteren. De praktijk van het routinematig implanteren van deze sondes bij SAB patiënten die klinisch niet te evalueren zijn, begon omstreeks 2014 in de afdeling voor neurochirurgie te Aken. We vergeleken alle SAB patiënten sinds 2014 tot 2018 met een controle groep van patiënten voordat invasieve neuromonitoring gebruikt werd. De nadruk van ons onderzoek lag hierbij op de vraag of het registreren van deze waarden bijdraagt tot een vroegtijdige detectie van relevante episoden van zuurstoftekort in vergelijking met een patiënten collectief waar deze techniek nog niet voorhanden was. In de groep van patiënten die met invasieve neuromonitoring waren uitgerust, werden afwijkende metingen bestempeld en dan ook behandeld als ischemie. De behandeling in de klinische praktijk bestaat uit verhoging van de arteriële bloeddruk om zo de cerebrale perfusiedruk te verhogen. In gevallen waarin deze behandeling niet aanslaat, vormt intra-arteriële toepassing van vasodilatatoren als nimodipine het volgende behandelingsniveau.

In onze voor en na analyse kon worden vastgesteld dat het gebruik van invasieve neuromonitoring bijdraagt tot een vroeger detectie van ischemische episoden en zo leidt tot een sneller begin van behandeling in de correct geïdentificeerde patiënt. Zoals gepresenteerd in hoofdstuk drie, vertaalde dit zich wederom in een verminderd aantal herseninfarcten en een beter klinisch toestand van patiënten omstreeks een jaar na de bloeding. Ook in een subgroep van patiënten die initieel wel klinisch te onderzoeken waren maar ten gevolge van latere complicaties niet meer bij bewustzijn bleven, werden sondes geïmplanteerd. In de analyse van deze data, gepresenteerd in hoofdstuk vier, kon vermoedelijk ten gevolge van de geringere grootte van de patiëntengroepen, geen verschil geïdentificeerd worden in de klinische toestand van deze patiënten in vergelijk met patiënten zonder invasieve neuromonitoring. Wel kon worden vastgesteld dat na implantatie van deze sondes, patiënten minder hoefden te worden getransporteerd door het ziekenhuis voor medische beeldvorming. Tijdens de klinische besliskunde werd meer berust op de aangeleverde data om de behandeling van ischemie te sturen en af te bouwen in vergelijking met patiënten waar deze data niet voorhanden waren. De reductie van het aantal transporten van patiënten op intensieve zorgen is relevant daar dit telkens een risicovol maneuver betekend tijdens hetwelk complicaties kunnen ontstaat. Bijkomend draagt het verminderd aantal radiologische onderzoeken bij tot een reductie van de blootstelling aan ioniseerde straling. 
Samengevat dragen deze resultaten bij tot een ondersteuning van de evidentie aan te bevelen patiënten met subarachnoïdale bloeding die niet klinisch te onderzoeken zijn te monitoren met behulp van invasieve hulpmiddelen. 